\title{
Enlivening vast green spaces of Zamość. Spatial organization of key recreational areas of the Town. Planty
}

\author{
Katarzyna Kielin \\ https://orcid.org/0000-0001-5370-5686 \\ k.kielin@pollub.pl \\ Department of Architecture and Urban Planning, Faculty of Civil Engineering \\ and Architecture, Lublin University of Technology
}

\begin{abstract}
Today's city longs for air and green. Congestion, overflow of car traffic, the pace and randomness of contemporary living might serve as plights for the spaces around us since one might observe accruing amounts of waste produced by humans, pollution or disorganization/ inconsistency/ incongruity of public spaces. Quite threatening might that be, but there has been observed a 'trickling', continuous shift of a social life towards virtual reality of tempting, alluring social media, games, news on-and-on broadcasts, shopping websites. We engage in perversely intimate relation with our 'cuddle-to' electronic devices - phones, laptops, smartphones. Little Prince would not be happy with 'our establishing ties' with lifeless machines, would he? Getting children out of their computers to kick some ball or play hide-and-seek turns into changing the current of a river or tempering with a bee. It will definitely stab you. Can a historically charged, conservatory space be a no space?
\end{abstract}

Keywords: Planty, Zamość, public space, recreation, heritage

\section{History}

The area of today's Planty used to play a strategic role in the plans of the development of the centre prepared by an engineer Władysław Siennicki in 1880. When Prof. Jan Zachwatowicz, together with a group of students, came to Zamość in 1933 he was amazed at its attractiveness as a town of great historical significance. The visit was an incentive to carry out research on restoring the Zamość original architectural splendor. His work resulted in the preparation of a master plan for the Town which included probably the first delimitation of a preserved area in terms of its historical substance. ${ }^{1}$ Earlier, the terrains around the northern part of the fortress served as a military training area (The Borodiński Square) which was visible on the 1916 Plan of Zamość ${ }^{2}$. The plan from 1939 proposed vast green areas around the fortress in order to expose architectural structure of the town. ${ }^{3}$ The plan stressed clearly defined historical centre which ought to undergo thorough revalorization process as well as delimiting directions for its wide development. 'The Zamość Old Town were supposed to perform a role of a prestige centre with unobtrusive, minor services and venues for administrative purposes. ${ }^{4}$ The plans were to restore the overall outline of fortifications and supplement the most immediate surroundings with designed/ arranged greenery that would follow the line of the walls. Park-like green areas were planned whereas, to the

1 Zamość miasto idealne, Studia z dziejów rozwoju przestrzennego i architektury pod redakcją Jerzego Kowalczyka, Wydawnictwo Lubelskie, 1980 edit. Jadwiga Kaliszuk, ISBN 83-222-0125-7, p.

2 Situazionsskizze der Stadt Zamość samt Lubliner Vorstadt und Nowa Osada (1916)Österreichsches Staatsarchiv Wien, Kriegsarchiv, Glk $161-10$.

3 Szkicowy projekt planu zabudowania, skala oryginału 1:10000, wyk. Jan Zachwatowicz, Władysław Wieczorkie-wicz, 1939 r. Źródło ilustracji Archiwum Państwowe w Zamościu, Biuro Planowania Przestrzennego w Zamościu, spis zdawczo-odbiorczy nr 5, I.p. 54

4 Przegon W., Żygawski J., "Kartograficzne Zamostiana", Kraków - Zamość 2018, W stulecie odzyskania przez Polskę niepodległości 
north of Planty, up to three-storey development with a maximum of $45 \%$ of built-up area was proposed as well as the area called 'użyteczności publiczne' (public services area). ${ }^{5}$ The Planty area is incorporated within the Zamość military landscape which is also referred to as a military park ${ }^{6}$.

The Planty residential district was placed along the southern part of Róża Luxemburg Street (today's Peowiaków Street) stretching across the previous terrain of historical fortifications. Its construction was divided into stages and continued between 1956-1972. The development was designed by two architects - Stanisław Król and Zofia Haman. The ongoing process of a continuous development of the area was supervised by the Waleriana Łukasińskiego Cooperative Housing Association and resulted, among others, from a constant steady growth in the number of Zamość residents from 1960 till 1975 (average 3 to 4 thousand per a 5-year - period). The year 1956 brought a remarkable growth in the development of single-family, two-storey and apartment buildings which differed significantly from a more traditional landscape of low-rise, wooden developments accompanied by little gardens. In 1965, the Łukasińskiego Association cooperated with PSS (a Polish Consumers' Co-operative), Ruch and TPD (Children's Friends Association) in the preparation of recreational and educational offer for the residents of the Planty district: a recreational halls for youth/ rooms, do-it-yourself corner/ nook, groceries store, children's playgrounds during spring-summer season, klubokawiarnia (cultural club), music section, tv set and record player in the children's recreational room, nutrition, sewing courses for adults, beauty cosmetics shows. They arranged occasional social meetings such as 'Andrzejki' (St. Andrev's Eve parties) 'Sylwester' (New Year's Eve parties), 'Ostatki' (Shroave Tuesday parties), introduced chess - and - bridge nooks and lectures prepared by Common Knowledge Committee). ${ }^{7}$

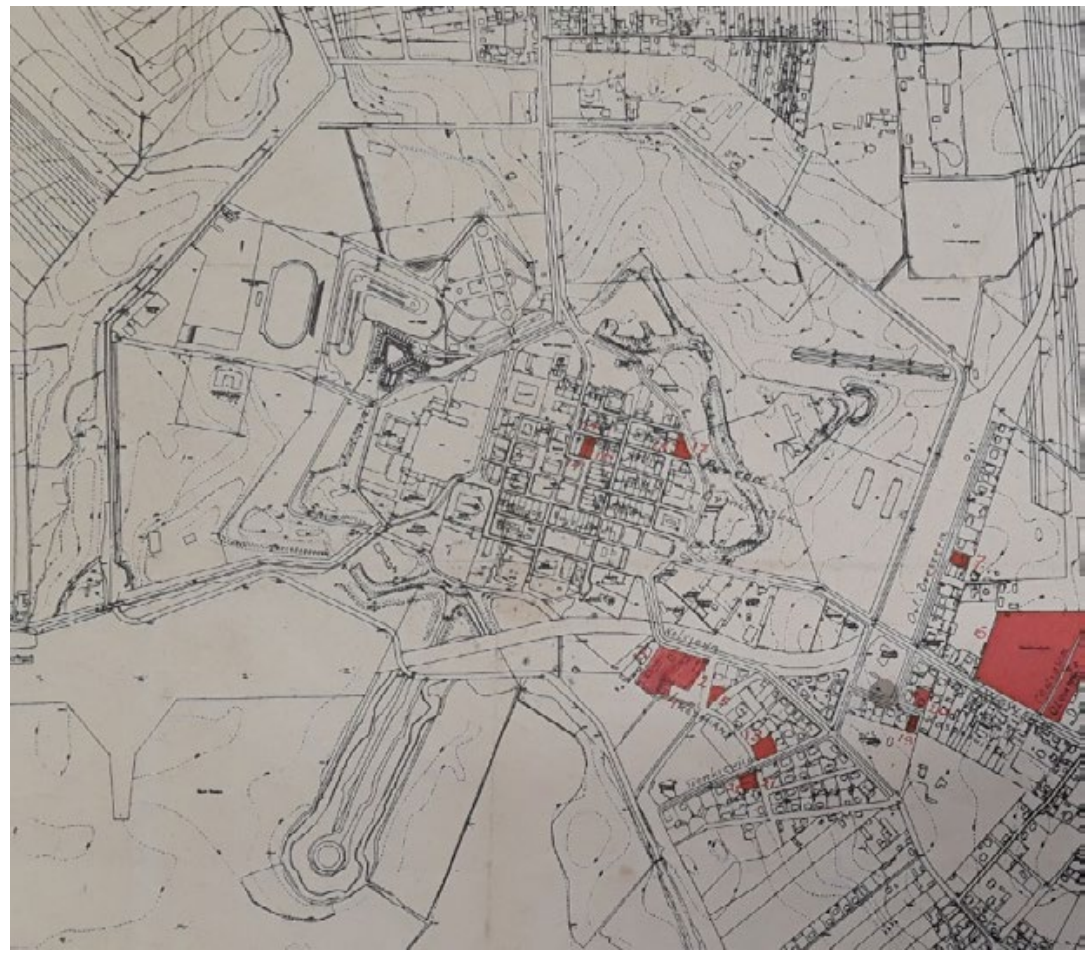

Fig. 1. Plan miasta Zamościa (1939 [1945]) Archiwum Państwowe w Zamościu, Akta miasta Zamościa 1915-1944, sygn. 216, s. 26.

5 Szkicowy projekt zabudowania Zamościa (1939)Archiwum Państwowe w Zamościu, Biuro Planowania Przestrzennego w Zamościu, spis zdawczo-odbiorczy nr 5, I.p. 54.

6 http://infomaty.zamosc.pl/pl/page/87/; website access: 28. 11. 2019

7 I want to express my gratitude to the Waleriana Łukasińskiego Association for sharing archival information about the history and functioning of the Association and the Planty district 
The Zamość historical centre together with fortifications was enlisted into the Register of Monuments in 1936. ${ }^{8}$ While it was included into the UNESCO Cultural Heritage in 1992.

The Planty District was among three most problematic terrains out of a total of 16 districts in Zamość. They were qualified as degraded areas which demand immediate attention and Planty, together with Stare Miasto, required revitalization measures. The Local Revitalization Program for the Town of Zamość was planned for the years between 2017 - 2023. Significantly a big number of people (39/ 100 people) experiencing various social problems such as a chronic disease, alcohol addiction, single- parent or multi-children families, disability, underprivileged circumstances.

The implementation of a cornerstone into a future amphitheatre was carried out in 1969. The whole construction was built by the citizens of Zamość, as the Polish authorities had expected at those times. Even though the shape of the audience part was reversed with regard to the original outline of the ravelin, the place was frequented by the Zamość residents for entertainment events such as concerts, dancing performances.

The map shows delimitation of the Planty area from the north and the remnants of the fortress walls.

\title{
Examples of using green spaces of a city
}

\author{
Planty form a city garden, destined for walking, widely accessible from their beginning, \\ being a natural ornament for the historic core of Cracow. ${ }^{9}$
}

\section{Prof. Janusz Bogdanowski}

The Cracow Planty area spans across $20 \mathrm{ha}$ and circles historical centre for about $4 \mathrm{~km}$. The history of the formation of the Cracow Planty dates back to first quarter of the $19^{\text {th }}$ century. They form a series of 8 gardens which take their names from characteristic objects and places situated in the consequent areas. Unlike the Zamość Planty, they were planned (after 1820) to become city gardens after the decision to demolish the city defense walls and level the moats. They perform aesthetical, recreational and symbolic function as they serve as an open - air gallery with sculptures commemorating very important events for the Polish nation. The spiritus movens of a plan for the arrangement of Planty was prof. Janusz Bogdanowski ${ }^{9}$. The complex was divided into 8 parts in 1972 during conceptual design managed by prof. Bogdanowski in the Institute of Landscape Architecture, at the Cracow University of Technology. Revitalization works began in 1985 while, throughout the 1990', the decision was made to expose the layout of previous fortification walls and mark the location of historical towers and gates by means of masonry tablets designed by prof. Stefan/ Stanisław Dousa.

Playground 'Plantuś' in The Cracow Planty area takes some inspiration from historical, archeological discoveries near Archeological Museum. Throughout 50 years the space used to function as a masonry facility. In 2015, the Municipality of Cracow leased the terrain from the Archeological Museum. The design was prepared by Pracownia K., and built by GAJDA Architektura Krajobrazu (GAJDA Landscape Architecture Studio). The terrain offers playground facilities which refer to certain objects and places present in the old times. A child can experience a wonderful adventure of travelling in history and learning about ways and places people used to live in. Some parts of the playground resemble a cave, simple huts, cottages, traditional tenement houses. There are some toys and little boards on the walls referring to certain archeological objects. The greenery planted in the area, in their colours, has a symbolic reference to the colours of the City Of Cracow - white and blue as well as it is grown with the species typical to the aforementioned historical places of residence (placed next to the facilities). The playground is divided into 5 stripped zones with a central 'market-like' space devoted to the organization of various types of workshops, theatrical performances, family events. The authors of the space introduced multisensory, universal solutions which target a variety of users, including those with different

8 Jawor A., Kultura w mieście idealnym. Kultura - Zamość - Uczestnictwo w kulturze. Korporacja Polonia Warszawa 2009, https://books. google.pl/books?id=4qqDQvla4QEC\&pg=PA82\&dq=Zamo\%C5\%9B\%C4\%87\&hl=es\&sa=X\&ved=0ahUKEwipj92foo3mAhWDs4sKHbH6DDYQ6AEIKDAA\#v=onepage\&q=Zamo\%C5\%9B\%C4\%87\&f=false; webpage access: 28.11 .2019

9 Renowacje i Zabytki, No4 2006, Kwartalnik Ogólnopolski, index 36956X, ISSN 1643-2029 
disabilities. At the entrance to the playground, apart from a regular information board, there is a tyflographic tablet for people with eyesight impairments which explains the organization of the space.

\section{Chart No 1}

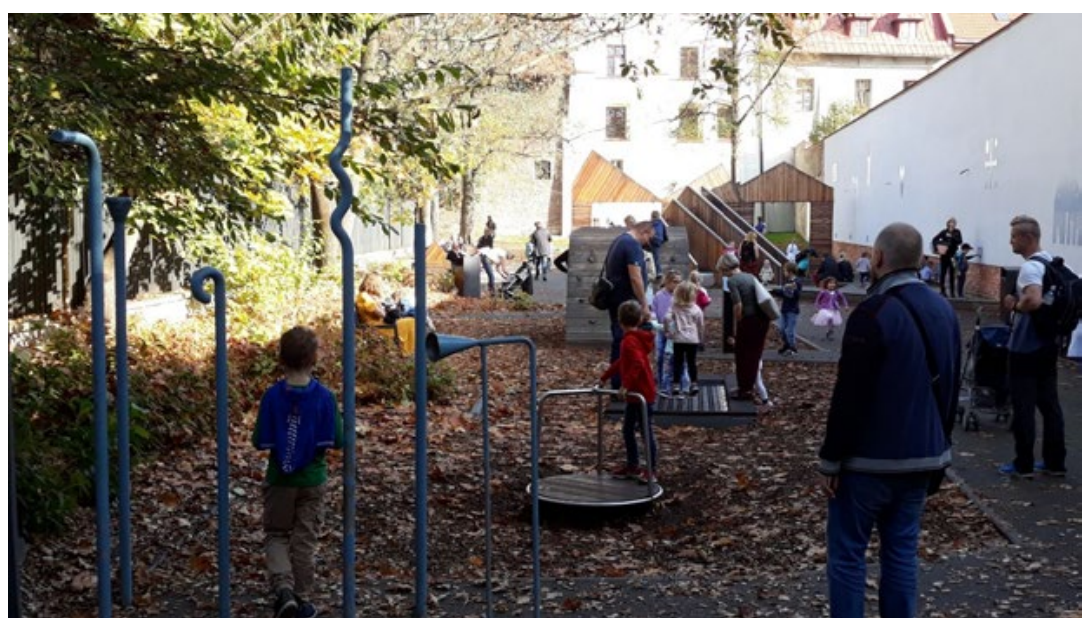

Fig. 2. A view towards the "Plantuś" playground, the Cracow Planty, premises of the Archeological Museum in Cracow, Source: $\mathrm{K}$. Kielin, Widok w stronę wnętrza placu zabaw 'Plantuś', Planty, Kraków; źródło: K. Kielin

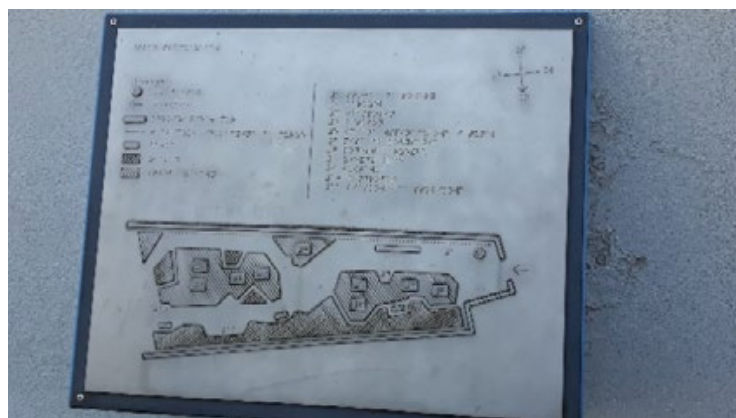

Fig. 3. A tyflographic tablet at the entrance to the 'Plantuś' playground, the Cracow Planty, premises of the Archeological Museum in Cracow, Source: K. Kielin, Tablica tyflograficzna przy wejściu na teren placu zabaw 'Plantuś', Planty, Kraków, źródło: K. Kielin

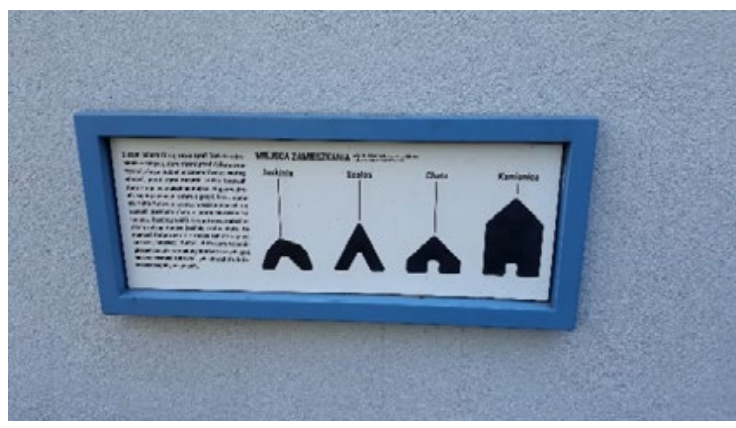

Fig. 4. Educational tablet presenting various models of habitation: the cave, hut, cottage house, tenement house, the Cracow Planty, 'Plantuś' Playground, Cracow, Source: K. Kielin, Tablica edukacyjna prezentująca różne formy schronienia: jaskinia, szałas, chata, kamienica, Planty, Kraków, źródło: K. Kielin

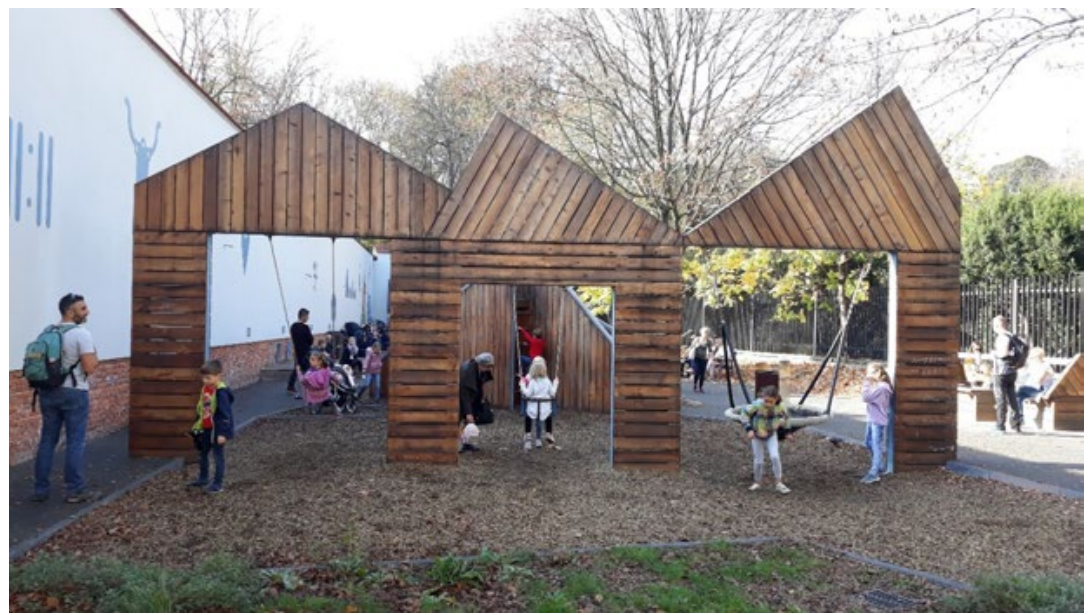

Fig. 5. Swings on the 'Plantuś' Playground arranged in a form of tenement houses, Planty, Archeological Museum in Cracow, Source: K. Kielin, Huśtawki na placu zabaw 'Plantuś' zaaranżowane $w$ formie kamienic, Planty, Kraków, źródło: K. Kielin 


\section{Playground area 'Dzikie Planty'}

'Dziekie Planty' children's playground ('Wild Planty') is located along Świętej Gertrudy St., close to the Royal Hotel and is thematically connected with a wildlife fauna. The objects present on the playground resemble worms, mushrooms, snakes, owls. The place is universally accessible as there are sitting places positioned at different levels, the playground objects provide multisensory experience. The elements are made of wood. One might see the world through a magnifying glass.

\section{Chart No 2}

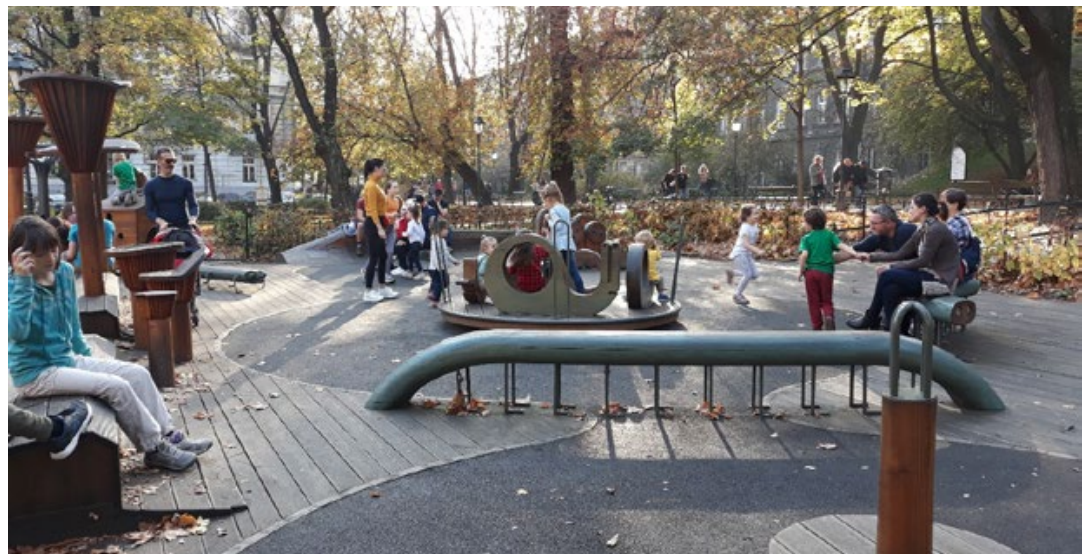

Fig. 6. 'Dzikie Planty' children's playground, Św. Gertrudy St, Cracow Planty, Source: K. Kielin; Plac zabaw 'Dziekie Planty', ul. Św. Gertrudy, Planty, Kraków, żródło: K. Kielin

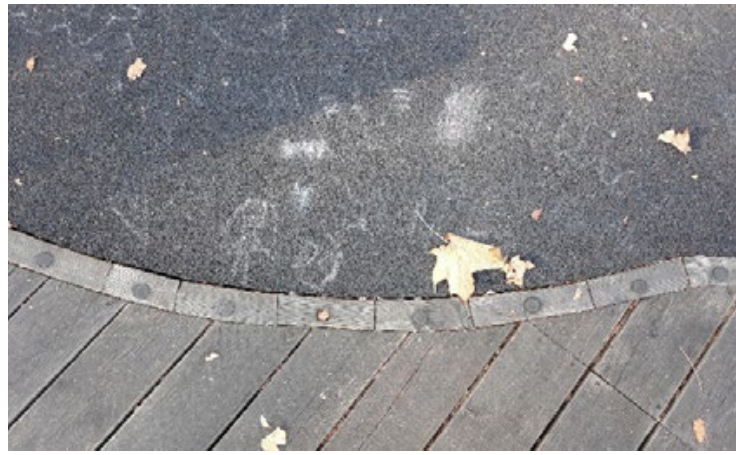

Fig. 7. Playground surface, 'Dzikie Planty', Cracow Planty, Source: K. Kielin, Nawierzchnia placu zabaw, 'Dzikie Planty', Kraków, źródło: K. Kielin

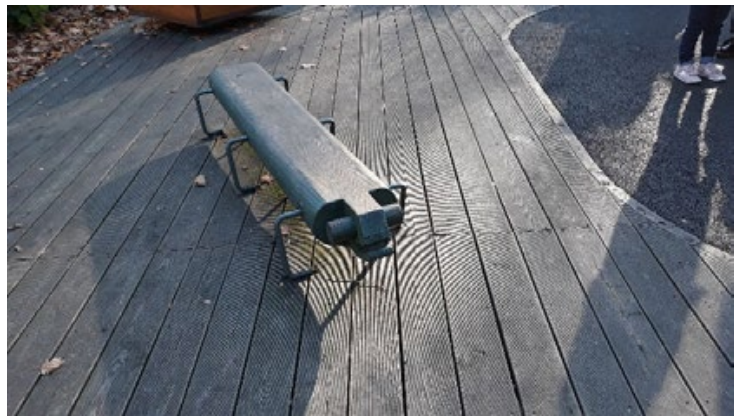

Fig. 8. Playground surface, an example of a piece of playground furninshing, 'Dzikie Planty', Cracow Planty, Source: K. Kielin, Nawierzchnia placu zabaw, przykład urządzenia zabawowego, 'Dzikie Planty', Kraków, źródło: K. Kielin

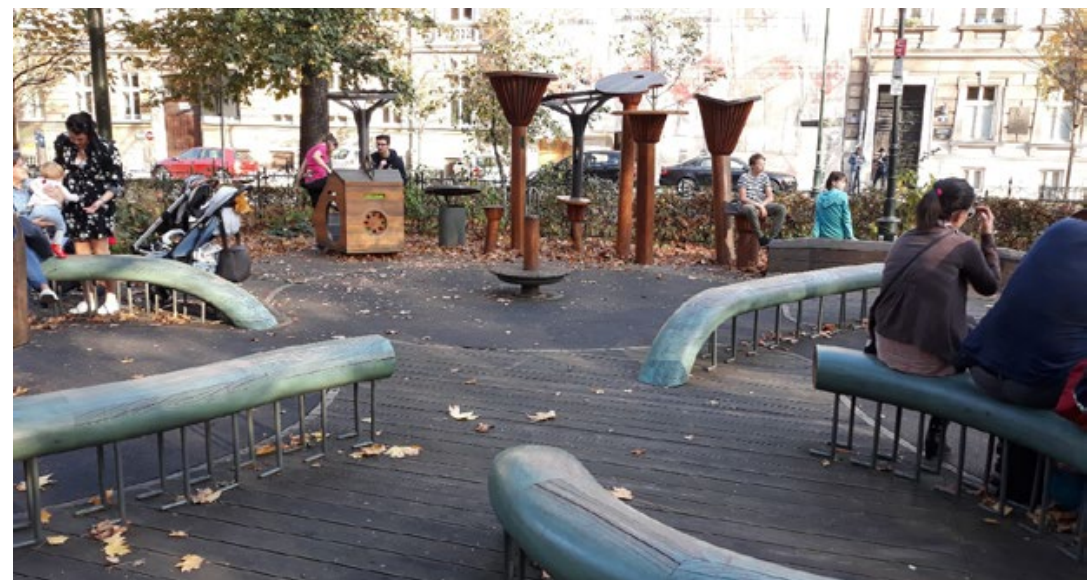

Fig. 9. Playground surface, 'Dzikie Planty', Cracow Planty, Source: K. Kielin 
'Galeria pod Gołym Niebem' is an initiative instigated by the Anna Dymna Foundation 'Mimo Wszystko' about thirteen years ago and held on the Cracow Planty during spring/ summer season. The event, animated and prepared by volunteers, encompasses workshops, an open - air gallery of works of art (paintings, sculptures, toys, clothes, graphics, ceramic objects, jewellery and many more) handed in by different artist, friends to the Foundation, generous donors. This year's edition (15-16 June) was aimed at gathering funds for adults with intellectual disabilities.

\section{Current organization of the Planty District}

The terrain in question consists of two major parts: residential and recreational. The development is composed of three - to five- storey buildings which were built between 1950-1970. Spatial organization of the place is very clear. Green areas around the fortification walls serve as a buffer zone. As far as z type of development is concerned, there is no gradual transition from the historical substance and a modern style of residential buildings. Most of the buildings are aligned along the north-south direction, positioned at a right angle towards Peowiaków Street, therefore, having east - west sun exposure. Structurally, it is a comb - like arrangement with a visual closure, in the south, given by a line of blocks facing the Planty area. The connection between residential neighbourhood spaces and the forefront of the fortress is distorted. Core layout of main pedestrian paths follows the line of fortifications. The walkways circumscribing the walls allow for a broad view of different elements of the fortress: curtain walls with cordon cornice and embrasures for firearms, bastions No VI and VII (reconstructed in 1970' and 80'), the New Lubelska Gate, retrenchments, counterguards, ravelins, remnants of the caponier. The exposition has a strong educational value since one can admire the monumental splendor of the fortress from the distance as well as spot key towers forming the Zamość skyline. Therefore, restrictions concerning the implementation of volumes of significant height should be strictly kept. The area of Planty is predominantly grassy terrain with randomly growing trees in the north -east side. North west side acquires some characteristics of a park with orthogonally led pathways and a handful of trees. Contemporary outlook of Planty is a result of consequent conservation process happening from the 1930' when some inventory works began. In 1976, the Zamość defensive facilities undertook noticeable transformations for the upcoming $400^{\text {th }}$ anniversary of the foundation of the Town. But it was not until 2011 that the Fortress landscape underwent vast renovation co - funded, to a great extent, by the European Union. The European Union input came from the project: "Zamość - a UNESCO Town, Historic Monument of Poland - Tourist Product of Polish Economy" under Activity 6.4 of Operational Programme Innovative Economy "Investment in Tourist Products of supraregional significance." The municipalities of Zamość filed the project in May 2008. Out of a total of 175 projects submitted for verification and financing under the Activity 6.4, only 13 were chosen, among which the Zamość project being the only one selected from the lubelskie voivodeship. The project begins a Zamość fascinating journey towards becoming one of the most important centres of historical and military education. Such distribution enables to form cameral green spaces but without proper street furniture facilities. The interiors are insufficiently equipped with playground and street furnishing facilities. In the majority of cases, the places to rest are located in the vicinity of building entrances, the courtyards remain covered with green which has no compositional predominant rule. One of the characteristic features of the areas around residential buildings are flower gardens along the ground floors. A specific aura of quiet could be felt within the courtyards. 


\section{Chart No 3}
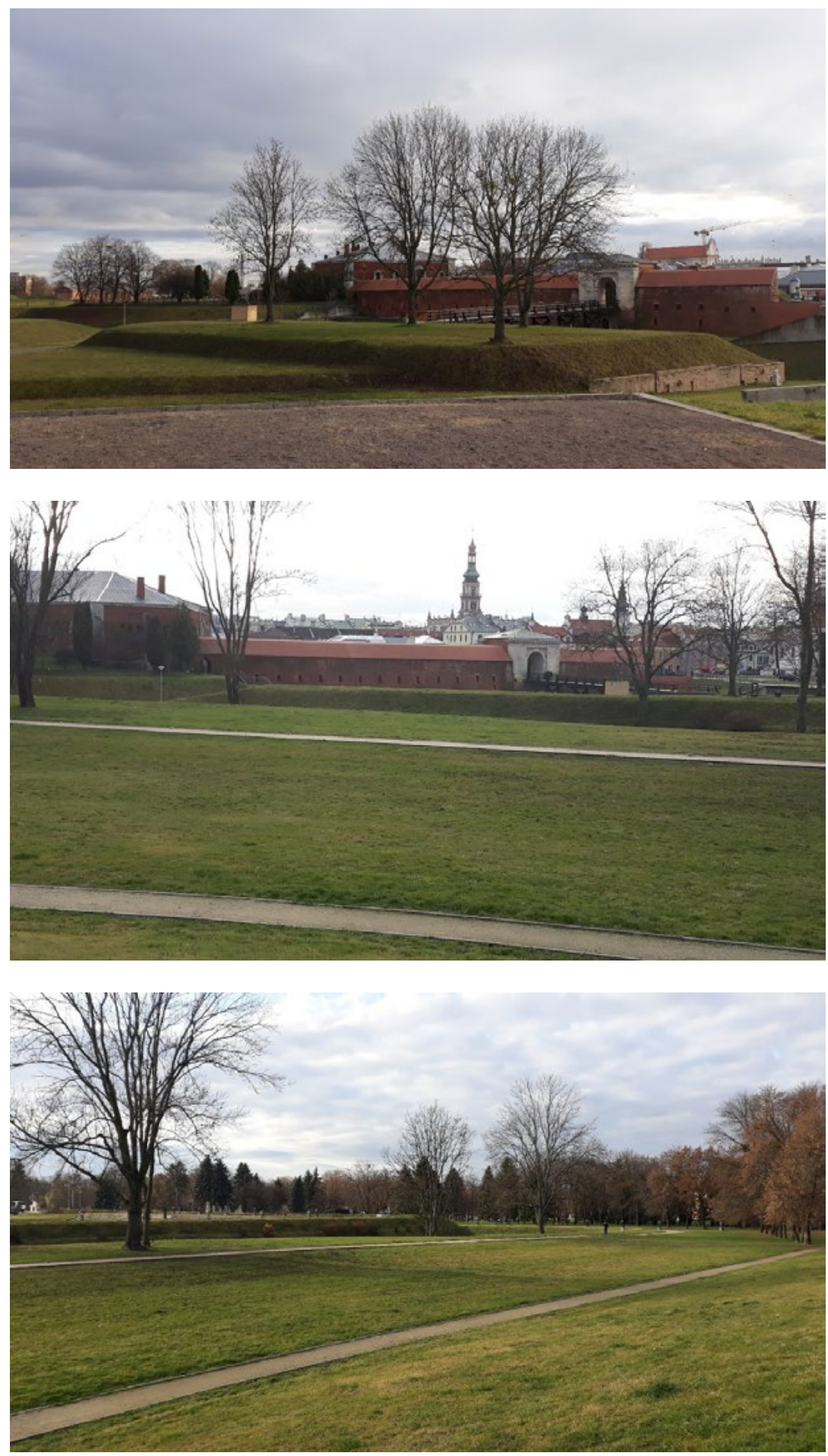

Fig. 10. Plateau of a current amphitheatrical stage, Planty, Zamość, Source: K. Kielin, Scena obecnej przestrzeni amfiteatralnej, 'Przestrzeń fortyfikacji i sztuki', Planty, Zamość, źródło: K. Kielin

Fig. 11. Source: K. Kielin,

Fig. 12. Source: K. Kielin 


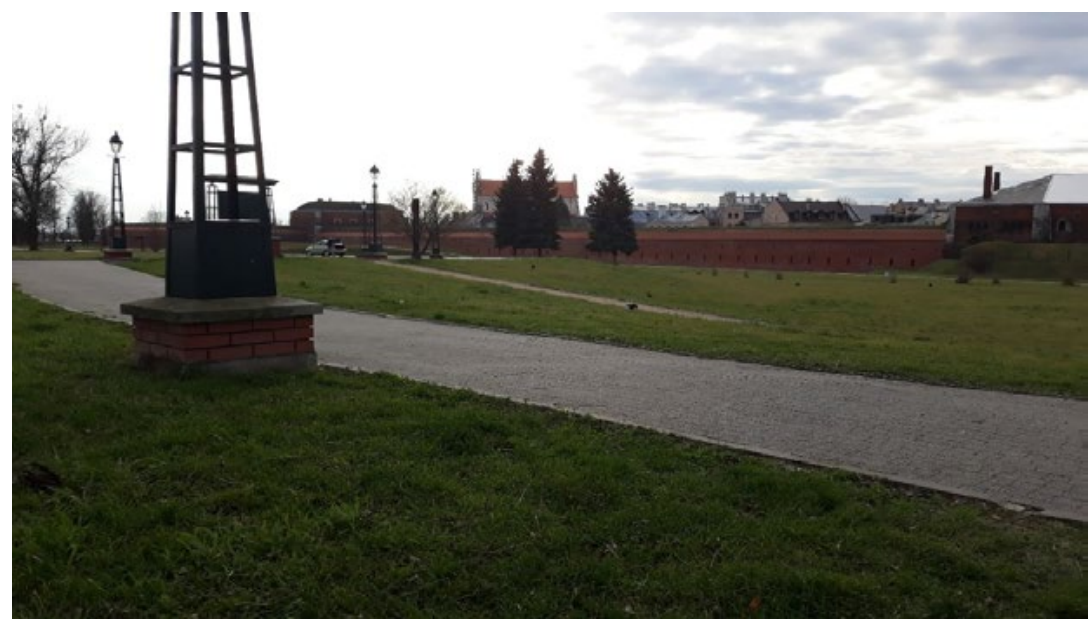

Fig. 13. Source: K. Kielin

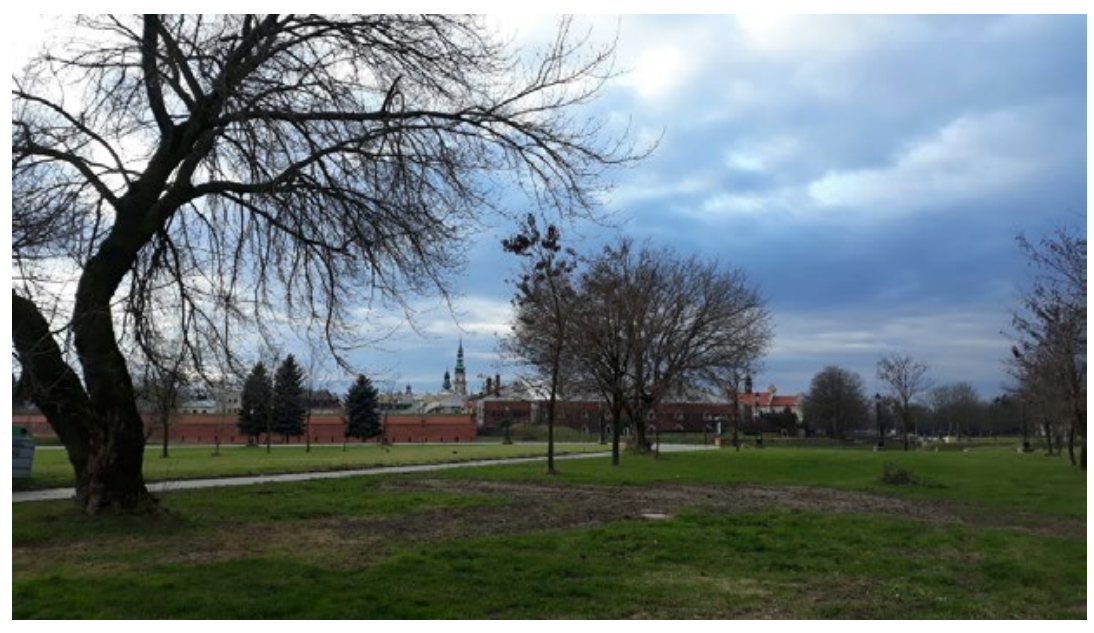

Fig. 14. Source: K. Kielin

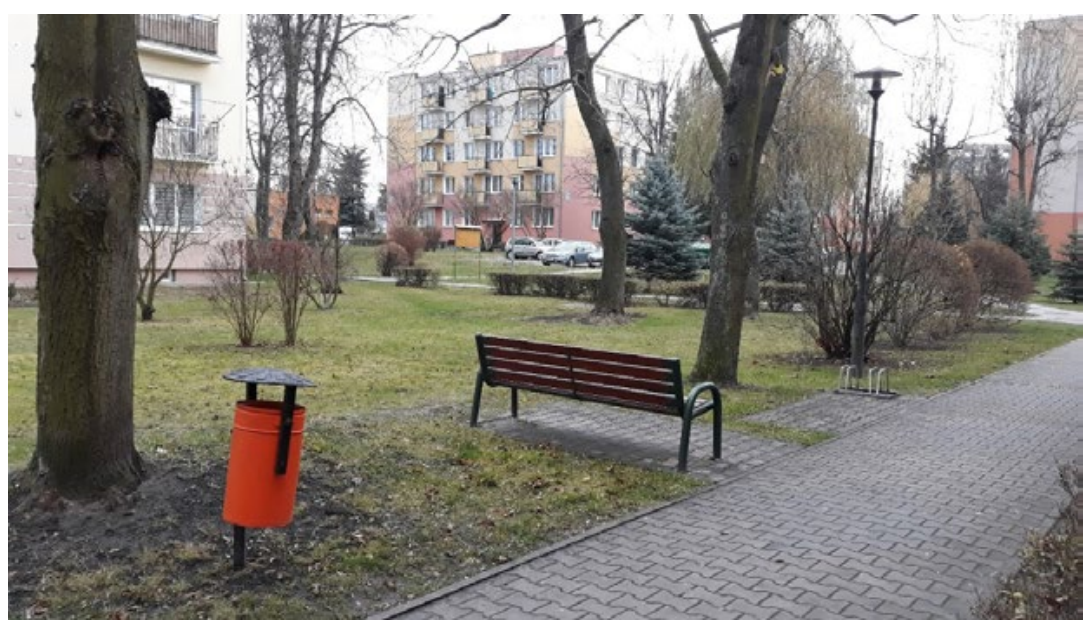

Fig. 15. Source: K. Kielin 


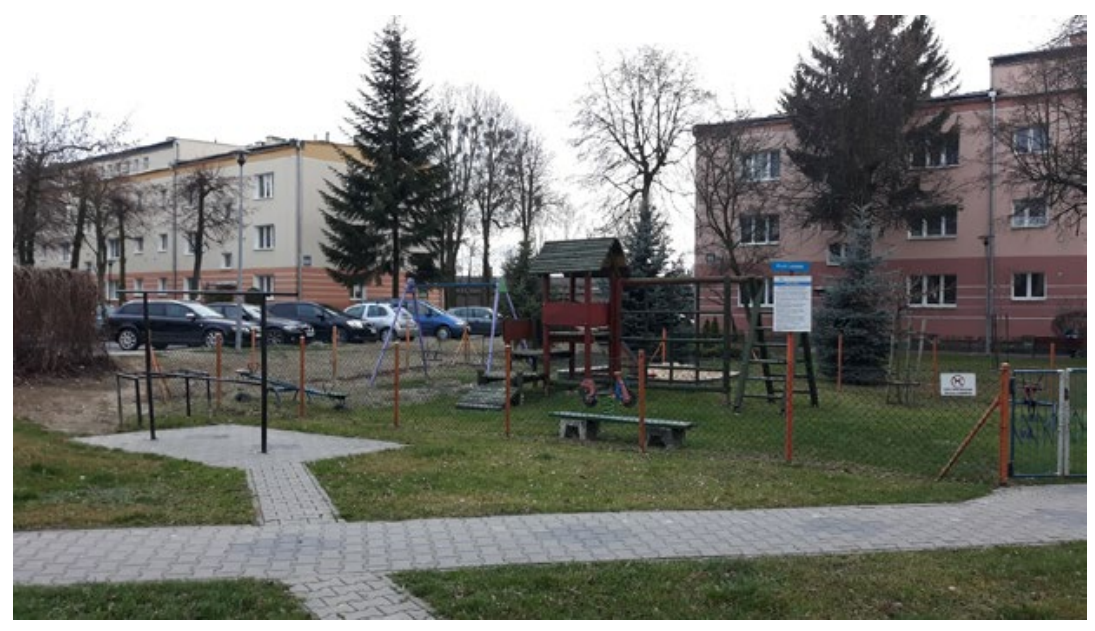

Fig. 16. Source: K. Kielin

\section{Current recreational offer in the analysed area}

'Wandering Stage' is a regularly held group of open-air events happening in several districts of Zamość like, for example, Karolówka, Partyzantów, Kilińskiego, Zamczysko and Planty. The meetings are designed to integrate families, people of different ages like seniors, children by participating/ engaging in interactive games, artistic actions such as:

Theatrical performances, theatre-based games and play, kids' play zones, beauty and wellness zones, arts - and - crafts zones, face painting, circus workshops, family music corner, sports games, medical prevention spots (e. g. measuring blood pressure), educating/ educative stands, meetings with managerial board members, under-the-stars disco, concerts.

The event is organized by the Zamość Cultural Centre together with the managerial boards of the residential districts taking part in the events as well as it is held under the patronage of the President of Zamość. It takes a form of a casual, on - blanket picnic gathering/ The participants of the 'Wandering Stage' are invited to bring blankets, picnic baskets and spend some fruitful time with their families in the open/ out of doors. Some initiatives tackle serious social issues such as today's problem of the lack of time among parents for their children which is presented in the form of an interactive theatrical performance entitled 'Tata bez krawata.' ('A Dad without a Tie'). ${ }^{10}$

There was also some tradition of inviting amusement park to the area as well as a circus. In the 1950', fairs were organised

Historical reconstructions of important battles held in the Zamość fortress. One of them is the Swedish siege of 1656 as a part of the Deluge, held by the Swedes under the leadership of Charles X Gustaw. Another event entails the commemoration of the defence of the Zamość fortress against the Bohdan Chmielnicki's troops. The two shows are also occasions to display skills and specificity of knightly brotherhoods, admire archers' abilities, horse-riding tactics, watch birds'-of-prey shows, historical art of dancing and historical pieces of clothing and armour.

Theatrical Summer in Zamość most often holds its place in the Great Market Square or the Zamość Cultural Centre. The amphitheatre located on the ravelin is rarely used as a stage space for plays while the skyline of the northern part of the Fortress could be a picturesque background for historical theatrical performances.

The Łukasiński Cooperative Association in Zamość holds rubber driven Flying Models Shows which take place at the Planty area. 


\section{Guidelines for the enlivening}

Comparing the Zamość Planty area with the Cracow one both have a very significant potential for cultural and educational development. Close vicinity to the city centre and an immediate, walking and visual, approach increase the chance of visiting those spaces by a great number of people.

- Increase in cultural events which promote architectural and urban values of the Town

- Increase in the organization of sports events (Plaża Open, AquaWave, engaging more people in sport)

- Activating the residents of the district

- Artistic workshops, students' workshops

- Engaging school kids in outdoor activities

\section{Conclusion}

'The problem of merging urban and architectural legacy with current needs of a contemporary city is of a distinguished importance for the establishment of contemporary conditions of its development. ${ }^{11}$ Plans for the incorporation of more recreational, educational and cultural events at the Planty area should be taken into consideration by the Zamość authorities insofar as they include serious, clever ideas based on studious materials of the Zamość architectural and urban value. The introduction of different festivities remains influential for people's cultural and educational growth as well as correlates with the Town's overall touristic image. The events and actions, the Town promotes, matter and has a strategic significance for the economic development and the levels of prominent investment. Inner parts of the town, quite understandably, attribute the greatest attention from both the residents and in-comers. A shift in that paradigm would have a refreshing effect on both the residents and municipalities. Reevaluation of a prime function of the space, which is mainly pedestrian, might be useful. Strategic goals for the development of the Town should base on an in-depth cultural and educational strengths in the historical context of Poland and Europe. 